1

\title{
GENERAL $g$ ELECTRIC
}

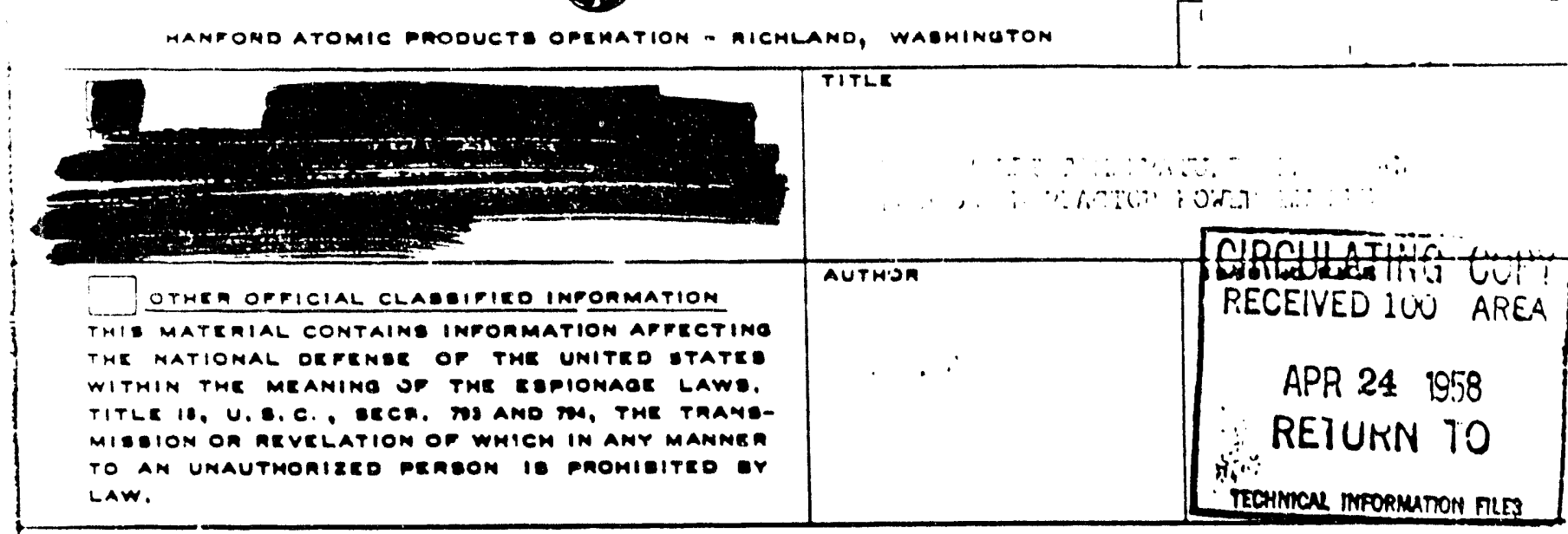

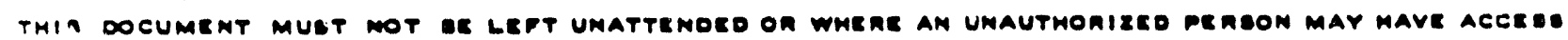

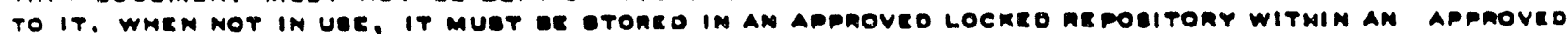
OUAMDED AREA. WMILE IT IS YOUA POEBRSDION AMD UNTIL YOU MAVR OUTAIMRD A OIOMRD AECEIPT FROM

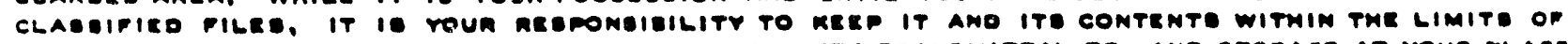

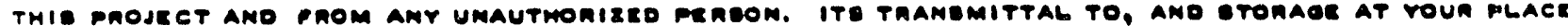

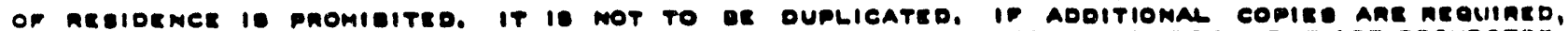

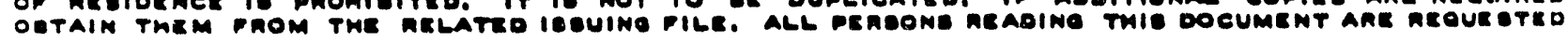
TO SION IM tME OPACE PROVIDED DELOW.

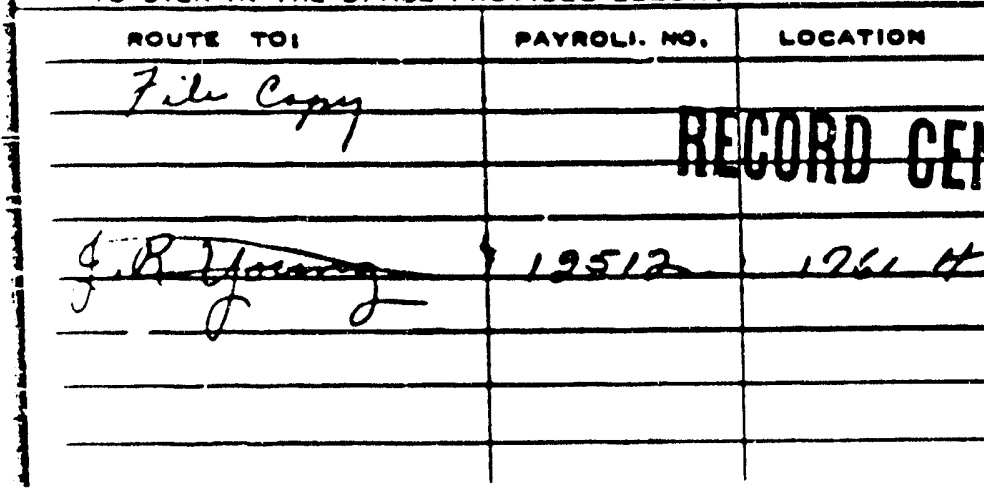

DISCLAIMER

This report was prepared as an account of work sponsored by an agency of the United States Government. Neither the United States Government nor any agency thereof, nor any of their employees, makes any warranty, express or implied, or assumes any legal liability or responsibility for the accuracy, completerness, or usefulness of any information, apparatus, product, or process disclosed, or represents that its use would not infringe privately owned rights. Reference herein to any specific commercial product, process, or service by trade name, trademark, manufacturer, or otherwise does not necessarily constitute or imply its endorsement, recom. mendation, or favoring by the United States Government or any agency thereof. The views and opinions of authors expressed herein do not necessarily state or reflect those of the United States Government or any agency thereof.
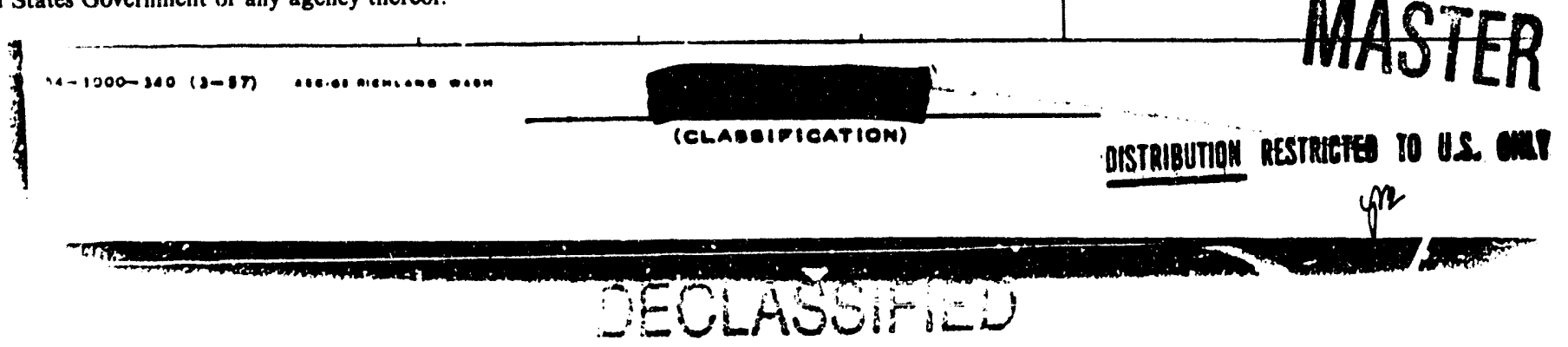


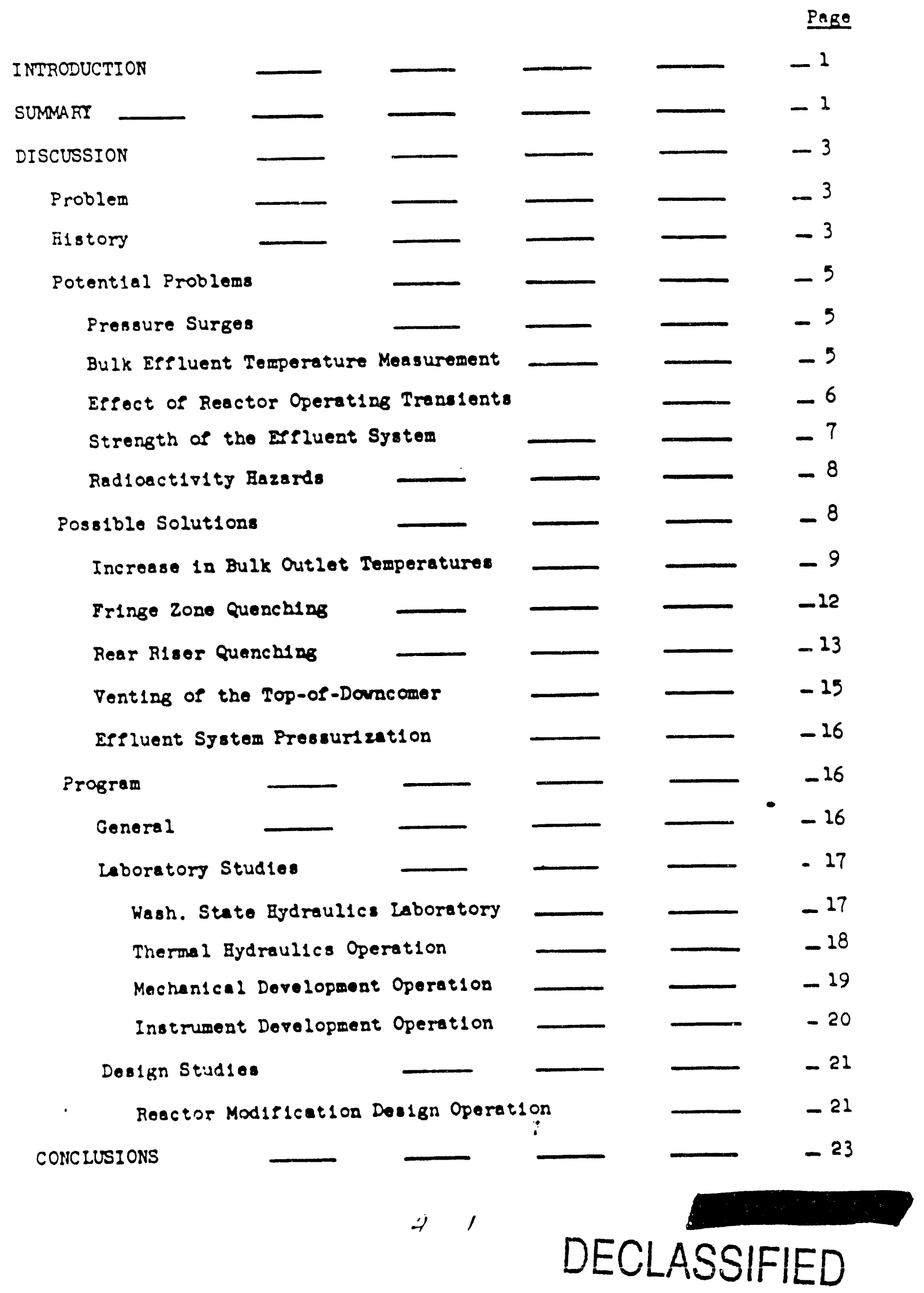




\section{DECLASSIFIED}

EW-5.5001 in

Pare 1

\section{DISTRIBUTION}

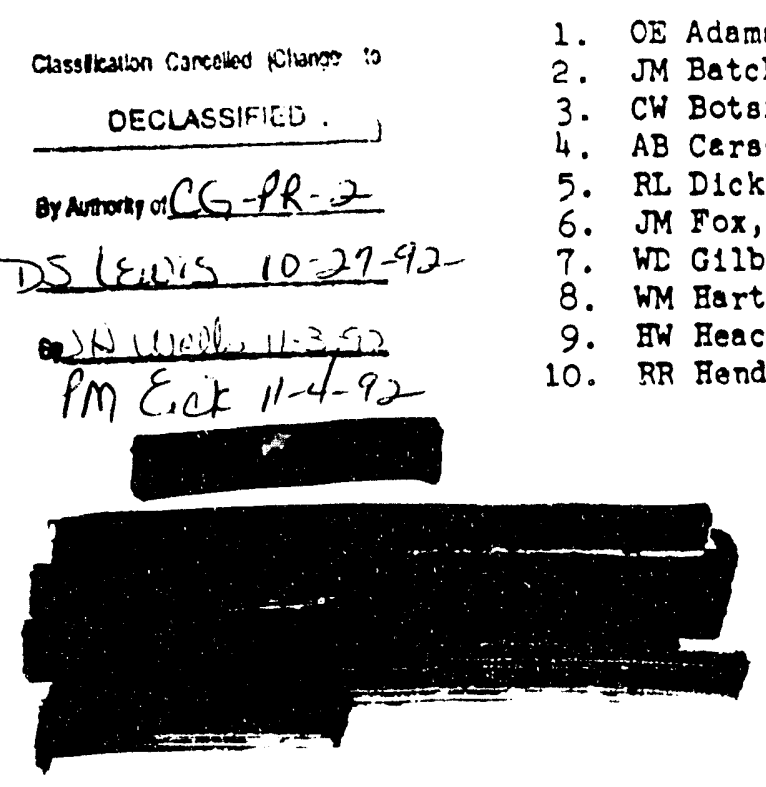

CUFY 1 OF 1

11. SS Jories

12. JE Kaveck1s

13. JF Mus1c

14. RW Rold

15. RM Smlthers

16. BG Spencer

17. Ww Windsheimer

18. 300 \$1les

9. HW HeacodD $\rightarrow 29$. File Copy

10. RR Fenderson

Th1s document con31sts. $O_{2}$

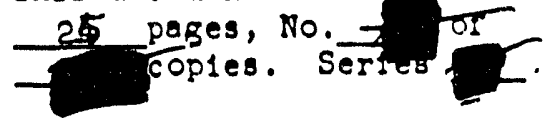

Thls document classifled by

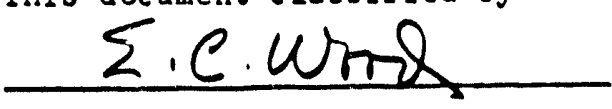

Apr11 21, 1958

BUTK OUTLET TEMTERATURE LIMITS AND INCREASED REACTOR POWER IEVELS

\section{INTRODUCTION}

In a recent report by $J$. R. Young means of clrcumventing the present bulk temperature 11mits are suggested. These have definite merlt but do not present an overali plcture of the problem. Therefore this bulk temperature 11ult is reviewed in order to place the problem in 1ts sull perspective. A program of action is suggested that should lead to elther:

1) Revised operating conditions and process piping to obtain higher power levels at the same bulk outlet temperaturo.

2) The completion of production tests to permit higher bulk outlet temperatures with no signiflcant changed in reactor plping.

The current roactor bulk out let temperature speciflcations will actually $11 \mathrm{mit}$ reactor power levels three to sour monthe in 1958 and poselbly all year in 1959. Since e reactor bulk temperature increase $0: 1^{\circ} \mathrm{C} 18$ worth about $\$ 100,000$

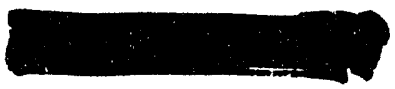


per jear, per reactor there is real incentive for elther raising this $11 \mathrm{mit}$ or c1rcumventing it by changes in the reactor system operation or plping.

Two Interim measures for increasing this production are:

1) Increesing the eringe zone reactor flow by opening the orfilce diameter.

2) Ra1sing the bulk outlet temperatures under carefully controlled production test procedures.

Increesing the eringe zone flow is relatively olmple but 1ts value is not clea: cut, and depends upon the interaction of process pump flow capac1ty and the central-zone and fringe-zone flow resistances. Since the central zone flow resistance is in the process of belng changed, power level increase by this method way to worthwh1lo in 1958 and of 11 ttlo value in 1959.

The present bulk effluent temperature I1m1t 18 besed upon a theoret1cal belance between the value of production gains and the estimated costs of possible effluent system damage. In plew of the theoret1cal nature of this l1mit a product1on test :s froposed to explore the possibilitiog of lncreasing 1t. The flrst pert ch this testing frogram w11 servo to substant1ate the current 11mits through ver1f1cation of the major reactor temperature transients. Upon complet1on of th1s and a possible bulk temperature $11 \mathrm{mlt}$ rev1s10n a further production test 18 proposed to investigate further outlet temperature increases. Poier level geins from this latter test are considered temporery because of the besic undesirab111ty of operating the reactor continuously so nes to the effluent line fallure conditions.

Three methods of c1rcumventing this bulk taraperature limit on a permanent bes1s are recomended for study. These are:

1) Add oold watar quanch to the boteom of the rear risera.

2) Vent the liberated gos and vapor from the top of the downcomer to the exhaust alr stack.

3) Completely presourize the effluent piping eyotem.

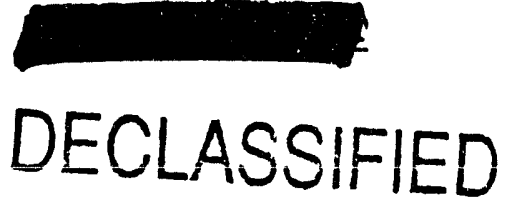


The most desirable of these methods cannot be selected unt1l a study of their feasibility and value 18 completed. Such a study is outlined in this report a long w1th the probeble general advantages and defocts of each.

In addition a program of laboratory testing is outlined for securing basic exper1mental data pertinent to reactor bulk outlet temperature $11 \mathrm{mits}$ and the system flow stab111ty.

\section{DISCUSSION}

Problem

Speciflcally, ou. problem 18 to determine how we can safety ralse the reactor bulk outlet temperatures up to $100^{\circ} \mathrm{C}$ or obtain the equivalent increased production by other means within the present 11mits. It 18 concelvablo that a reactor can be operated at $100^{\circ} \mathrm{C}$ bulk outlot w1th only minor operating problems. On the other hand, numerotis potent1al problems remain unresolved. Therefore, bulk temperature limits should only be increased under carefully controlled Production Test conditions. The value of such an increase, however amounts to $\$ 92,000$ per ${ }^{\circ} \mathrm{C}$ per year at an old reactor, or $\$ 196,000$ per ${ }^{\circ} \mathrm{C}$ per year at a K-Reactor. Th1s suppl1es the 1ncent1ve for a detalled study of this problem.

\section{H1story}

The original operation of the Hanford reactors was under the concept of "Excess Henter Pressure." (1) Th1s required that sufplcient header pressure bo ava1lable to sweep steam from a process channel if some temporary condition should cause it to be formed. Th1s requirement suffered from the linplicit assumption that the condition causing bolling was very transient. It considered that eseentially full excess hesder pressure was avallable to remove tho steam in a metter of a fow seconds after Its cecurrence in the pronas tube. Becouse of the inherent instablity of the reactor with respect to boling, 1.0., the goin in reactivity upon 108 of water to - tute, tonling to cause vaporization in surrounding tubes, etc., the provention or outlet bolling wes a cardinel requirement of reactor operation.

(1) W.K. Woods and H. Worthington, "Bo1ling in the F110," DUA-10169, Apr11 1, 1943. 


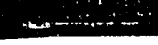

$\left.\mathrm{HW}-558 \mathrm{Cl} /{ }^{\prime} 1\right)$

Page 4

In 2054 the caceso hesder pressure reyuiferuent wa reiaxed to a requirement of trip-before-1nstabli1ty. (2) The Panellit gauges wero rovised and their maintenance 1mproved. As 1mproved slugs and water with 1mproved corrosion properties were developed, and as the graphite expansion problem was alleviated, the reactor power levels were ralsed to the point where tube outlet water temperatures approached $100^{\circ} \mathrm{C}$. The bulk outlet temperatures under transient cond1t1ons approached saturation Eemperatures at the top of the downcomer and the problems of bulk water bolling was cons1dered. (3)

It was polnted out that numerous potential problems were 1 noolved at $100^{\circ} \mathrm{C}$ bulk outlet temperatures; namely:

1) Unstable bulk flows at $100^{\circ} \mathrm{C}$ thet might cause tube bo111ng.

2) Caritation erosion and fat1gue fallure at the Parker fittings and

in the rear cross-headers.

3) Rad10activity problem from escaping "hot mist."

4) Loss of power level meesurement wherever two phase llow occurred upstream of the outlet temperature monltor.

As the program of Increased reactor flows and power levels continued, the $100^{\circ} \mathrm{C}$ bulk temperaturo problem shlfted in omphasis from considerat1on of overall effluent problems to the problems of the reactor tubes and charges. It wes concluded in a survej (4) that a fallure in the effluent sjotem would create no serlous problem and that supficient dato could be obtained in $4-6$ weeks to operate D-P1le at $100^{\circ} \mathrm{C}$ on a Production Test basis.

Fundamentally however, in the design of all the Hanford reactors the criterlo of no bulk boll1ns has existed $(5)(6)$ and in a more recent program report the unsolved

(e) K.0. Toyoda, "Tube Temperature I1m1ts by Tr1p-Before-Inotab111ty Concept," BW-32151, June 16, 1954.

(3) S.S. Jones, "Temperature Lim1to of the P1le Eesluent System," EW-31733, May 5, 1954.

(4) W.D. G1lbert, and 8. Goldsm1th, "P1lo Operation at B1gher Bulk Outlot Water Temperatures," HW-36415, Apr11 29, 1955.

(5) M.B. Russ, Design Criter1a," Vol. 1, Rev. 1, B-C Aroas BW-30401 V-1, R-1, Sept. 15, 1955.

(6) I.P. Bupp, V.R. Cooper, F.H. Woode1eld, "100 Areas Process Improvement Program for Perlod Apr11 156 - Sept. 156," HW-43040, Merch 31, 1956. 


\section{DECLASSIFIED}

HW -55801 RD Page 5

problems with respect to operation at $100^{\circ} \mathrm{C}$ bulk temperature are again emphasized. ${ }^{(0 ;)}$

To sumrarize the history of this problem, 1ts development has consisted of a gradual approach to the point where bulk bolilng considerations may soon actually 11 mit power level comblned with a wide varlation in concern about the problems that exlst and finally, fery $11 \pm t$ le progress tovards the determination of the actual magnitude of these proolems and their best sclutions.

\section{Potent191 Proklems}

At the present time the following problems rire foreseen as potential stumbling blocks to safe or satisfactory operation at $100^{\circ} \mathrm{C}$. Other problems mas appear as this program proceeds towards the achlevement of this goal of $100^{\circ} \mathrm{C}$ bulk outlet temperature. 1. Presgure Surges:

a. We hove made some top-of-downcomer pressure measurements that indicate that the system pressure at this polnt is essentially at atmospherlc pressure at bulk effluent temperatures up to $95^{\circ} \mathrm{C}$. Our messurements, however, were made with high Inertia maneters and do not give us ang accurate plcture or high srequency pibration or pressure surges. In add1tion, as the effluent temperatures reach $100^{\circ} \mathrm{C}$, the effluent bolling point, the vaporlzation effect may produce marked pressure surge effects. Sich surges represent potential problems both w1th respect to the effluent piping structural stablilty and possible process tube 1nstab111ty problems.

2. Bulk Effluent Temperature Meesurement

At the present time the bulk ef?lient temperature is measured downstream of ite reacior dowricomers. Whenever vaporization cocurs at the top of the downcomer

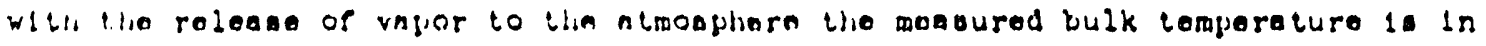
error. This error consists in tse iquid cooling produced by the flashing of water t.o bioam. Ir. additich to this error we have the problem of the current 15 is 30 second lime-lag teiweon a civiont tempereture change at the reactor and tho indicotion of this chenge in the control roow. The verlous problems posed by 


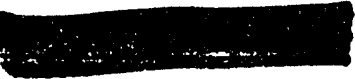

$\mathrm{HW}-\mathrm{E}, \hat{\mathrm{s} C l} \mathrm{l}$

Page to

this flashing error and time-log are discussed in the following sectlons.

\section{Effect of Reactor Operating Transients}

- Electrical Outage Efrects:

Tre $108 s$ of electrical power to a process pump or pumps ceuses an unavoldable outlet temperature surge as the process flow decreases before the reactor can be effectively scramed. By requirling a rapid electric trip of the reactor for the 1088 of power to any pump or pumps tinis transient temperature surge can te rediced to a minimum. Eowever, 11 wil alweys occur and mist be allowed for in establishing reactor bulk outlet temperature ilmits. If this Burge carries the effluent temperatlire above $100^{\circ} \mathrm{C}$ then two phasu flow wh a large increase in Pluld velocity will cecur or the system w11l become surficiently pressurized to suppress this bolling. The worst condition that might occur would be an irtermittent occurrence of both of these effects. This would present us with. both momentum and pressure stress effects on the low strength effluent system. b. Power Level Surges:

These can occur by inadvertant control rod movement, or po1son d1scharge, by excessive tube power levels and/or bolling in the central zone. They egaln pose the problem of holling and/or pressurization in the effluent system. With power level surges we have the added problem that lmediate reactrs scram will not be obtained. At the present time there would be a 10 to 15 peircent increase in power level before the reactor would recelve a scram signal. Thls means that power level surge effects are 1mportent parameters in considering reactor bulk temperature 11mits. This is described in dcte11 in a report to be 1soued, (7) and is summerized in a recent document. (8)

77) S. S. Jones, "Aralys1s of Bulk Outlet Water Temperatures, " EW-51327 to be 1 soued.

(8) S. S. Jones, "Reactor Bulk Outlet Temperature L1m1ts," EW-52793, March 6, 1958.

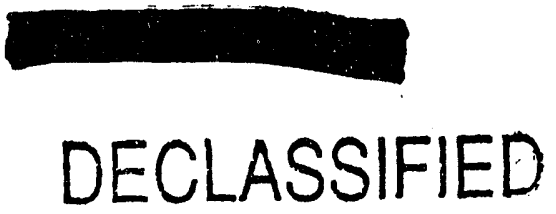




\section{DECLASSIFIED}

BW -55001 l'i Page 7

c. Feactor Fiow Decreases:

Aslde from pump problems reactor llow decreases can occur elther through process line valving or plping damage. The valve clcsing rates are slow enough so that rapid transient problems do not exist. Bowever, unless the proposed bulk water temperature monitor system (9) is in effect, we can have process rlow decreases of as much as 5-10 percent before a Panell1t trip of the reactor. Th1s would cause a corresponding increase in the bulk effluent tempereture. At the present time no power level allowance 18 made for the possible effects or a process line rupture. This is a calculated risk assumed by Manegement on the basis of the Importance of this plutonium production.

4. Strength of the Effluent System

A detalled analysis 1.3 in progress both of the strength of the effluent system and the pressurization effects produced by bolilng in the effluent sjstem at bulk temperatures in excess of $100^{\circ} \mathrm{C}$. (10) These celculations Indicate allaweble working prossures of $1-2$ psig and maximum bulk temperatures of $104^{\circ} \mathrm{C}$.

There are three critical points with respect to bo1ling in the effluent system.

a) The approach section to the darncomer.

b) The top of the downcomer.

c) The downcomer first cascade tray.

In the approech section we have the potential problem of stresses produced by flow momentum effects with a signiflcant increase in these stresses 1f two-phase flow occurs in the cross-over ine. In the downcomer with 1ts large rectengular crosi-section wa have the possiblety of fallure of the top to side welds at prossures above $1-2$ polg. Th1s corresponds to bulk outlet temperatures of 102 to

(9) 8.9. Junes, "Proposal for Improved Control of Bulk Ifeluent Temperature Surgos," EW-55486, March 25, 1958.

(10) O. E. Adems and S. S. Jones, "Critlcal Flow and Allowablo Work1ng Pressures at the Top of Ransord Reactor Downcomere," BW-54447 to be 1seued. 
itú: Tris depressurizazion wouid increase tre st.ress conditicrs both at the entrance elbow and the first cascade tray because of increased momentum errects with lover pressure.

Tre third point of weainess exists because of the possibllity of high mowentim effects on the top cascade tray of the downcomer. The fallure of this tray could cause severe flow reduction through the efeluent oystem and care mist be taken to prevent 1 ts occurrence.

\section{Redioectivity Bazards}

Cne furtier problem that way exist is the radiation hazard of large quantities of steam coming oif the top of the downcomer 1modiately after 1ts exposure in the reector. A conservative celculation of this effect could certainly indicate the magnitude of this hazard and whether ang special precalitions would be necessary.

Besides radicactifity problems at the top of the doracomer we also have the problem of 1ncreased radicactivitg at the retent1on besins. This could no doubt be randled by approprlate personnel restrictions adjacent to these basins.

Th1s represents the problems that are foreseen as potent1al difficulties in obtalning the desired $100^{\circ} \mathrm{C}$ bulk outlet terperature. Wags to clrcument all of these problems appear feesible, but the first step is to establish the actual megnitude of each one. Only after this bas been done for these problems, plus an additionel ones that appear as this program progresses, can we reach sound conclusions as to the best maner to froceed torards our $100^{\circ}$ bulk outlet goal. Possible Solutions

Although the full flcture of the problem 1 nrolred in achleriag this $100^{\circ} \mathrm{C}$ bilk outlet temperature is not known, it seems desirable to examine possible sulutions. This should serve to expedite the program of reeching the $100^{\circ} \mathrm{C}$ ganl. It howld also present a clearer pleture of the problems by 1 adicating both the operatiag difflculties lnvolved and the manner in whlch they can be

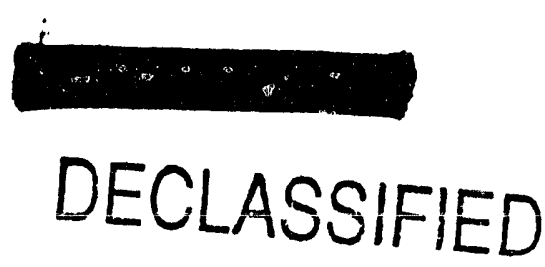




\section{DECLASSIFIED}

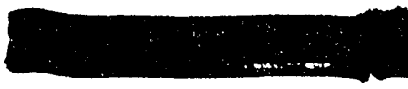

EW-55SCl $\wedge^{\prime \prime}$

Paga?

controlled or ellminated. For lnstance, the froblems of $100^{\circ} \mathrm{C}$ bulk outlet temperatures can be eliminated by quenchlng with cold rav water. Therefore, a number of different means of achleving the desired goal of 1acreased production are presented and andyzed in the following section.

A. Increase in Bulk Outlet Temperatures Under Production Test Cond1t1ons

Because the present bulk temperature l1mits are based upon a considerable amount of theory with respect to the effects of various reactor operating conditions upon the effluent flows and temperatures 1 w wll be very much in order to experimentally verify the magnitude of theee effects before proceeding with the main test of 1ncreasing the bulk outlet temperatures. Therefore the following prelimlary program 18 recommended.

1) Test Location: In choosing the reactor 1t 18 essential that it have two dowcomers and maxdmum flexibli1ty of operation. Therefore, C or B reactor will be selected.

¿) Fest Instrumentation: Because this 18 an exploretory test to determine the operating problems and possiblo effluent systen damage associated with higber sulk outlet temperatures very complete reactor 1nstrumentat1ori vill be required. The sollowing instrumentation changes or add1tions to the reactor are ant1c1pated: a. Ker bulk outlet tempereture sensing elements.

b. Transducer type pressure sensing elements to be lastalled in the cross-over 11ne and the domeomer.

c. Install f17e sol1d downstream dumb charges in widely spaced central tubes and lastall new high sensitivity ( $<1$ sec) callbrated tube outlot temperature elements. The temperetures of those elements should be simultaneously recorded

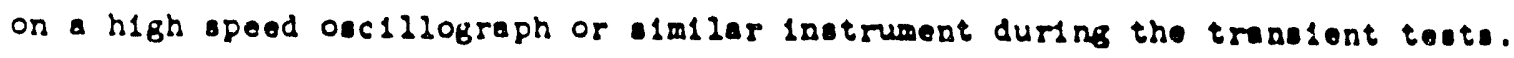
d. I7stall numerous otraln gago olements at critical polnt in the crose-orer and downcomer. Again these gages should be elmultaneously recorded durlng the transient tests.

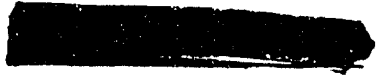


e. Install appropriate vibration instmixentation on the crosi-crer and downcomer to monitor anj dynamlc stress ccaditions.

: Instail any required upper crosa-hender oriflces to hardle the probleas of possible crosi-header boll1ng becalne of local high temperatures.

8. Install braces under the top cascacie tray in the downcomer to positively ensure that thls tray tallure does not occur.

3) Prelt=1rsm Tests: The foliowling preliminary tests should be made with th1s completely instrumented reactor to conflim our present theorles with respect to reactor transient effects and effluent system conditions:

a) BPA Outage:

1) During the first $\sim 30$ hour reactor shutdow efter completion of the described instrumentation complete instrumentation date should be obtained.

2) Upon start-up the reactor should be brought up to $45-55$ percent of rull level es repidy as 18 permitted and then beld at this level for fleteen minutes.

3) At this time the electrlcal porer to the 190-Annex process pumps should be tripped and the resulting BPA outage transients followed by the spec1al reactor 1 astrumentation.

4) The results of this test should be studied carefulig and compered with the theoretical results of EH-51327. (7)

b) Process Pump Tr1p-Out Test:

The flow characteristics and erequency of this transient are sufficientiy different from that of a BPA outage, that two tests are just1fled. Particularly when they both can be made wth only minor production 108ses. The sugsested procedure for th1s test 1s:

1) At the time of the elrot ocheduled reactor outage after completion of the overall test 1astrumentation the reactor should be shut down by s1rst trippling the power to a procese pump which has lta reactor trip signal by-pasoe! 17) Loc.C1t.

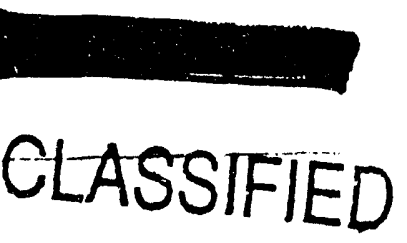




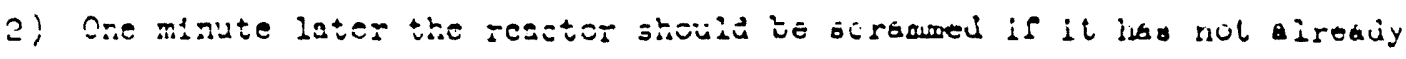
been snut-dom by the low-pressure trip of a process tube Panelilt gage.

3) Again the test results should be studied and compared with theory.

4) A review of these two tests should 1ndicate whether ang changes can be made in the bulk temperature limlts whthin the present basic analysis.

4) Increase in Bulk Outlet Temperatures under Production Test Cond1t1ons: This test proposes to carry a reactor up into a range of operation where posible effluent plpling damege may oceur. A detalled ansigsis of this problem has Ind1cated that eren Nith conservative est1mates of the gross costs associated with higher temperature operation there is strong indication that higher temperatire operation w11l be worthwhile, at least on a short term basis. Consequently this production test could serve to permit a production increase during the period of study and development necessars to make moro permanent and sat1sfactory increases in the effective bulk temperature 11mit.

The antlc1peted test procedure would be as follors:

a. Obtain botb "cold" and "hot" Instrumentation base-points read1ngs.

b. W1th the reactor at equ111brium rull $910 \mathrm{w}$, and $90^{\circ} \mathrm{C}$ bulk outlet temperature run controlled power level surgo up to $96^{\circ} \mathrm{C}$ and dorn to $92^{\circ} \mathrm{C}$ over a 10 mlsute elapsed-t1me period.

c. After complete analys1s of the experlmental data, 1.0., 24-48 hours, repeat this power surge test from $92^{\circ}$ to 98 and back to $94^{\circ} \mathrm{C}$.

d. Reperit these trensients for steps of 94 to 100 , 95 to 102 , and 98 to $104 \cdot \mathrm{C}$, with careful data analysis after each step.

e. Stop testing whenever dats is obtalned that indicates the probab1l1ty of effluent system damage.

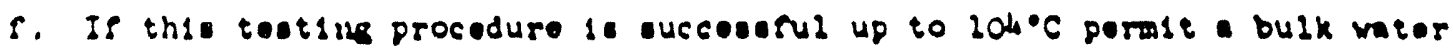
teinerature increase from 94 to $96^{\circ} \mathrm{C}$. 
HW -55801 h 'l!

Page 12

8. After a months' successiliz sperat1nn at this new temperature these transient test.8 should be repeated up to $110^{\circ} \mathrm{C}$ and reactor bulk outlet tomperatures of $98^{\circ} \mathrm{C}$ permitted 15 this second set of tests 18 successful. Becouse of the inherent problem of unavoldable temperature surges 1 w w11 always be necessary to operate the reactor some $x$ degrees below the peak allowable value. The purpose of this test is to evaluate the problems associated w1th these transients and $t \approx$ stablish both a peak temperature $11 m 1 t$ and a reasonable value for $r$ (the required decrease in nominol bulk limlt below this peak temperature).

B. Fringe Zone Quenching

As suggested by J. R. Young it is possible to increase reactor power level without an increased bulk outlet tempero'dro by lncreasing the wa " flow through the fringe tubes and allowlng a small increase in the outlet temperature and power level of the central zone tubes. In considering this proposal the following basic properties of the system are pertinent:

1) With a flxed bulk outlet temperature ang given 1ncrease in total reactor flow w1l give a constant increese in production, no matter how the reactor flow is distributed provided other tube ilm1ts are not exceeded.

2) The 1ncrease in reactor flow gelned by opening the eringe zone tubes w1I cause a decreaso in central zone flow corresponding to the effect of decreases im pump discherge pressure that occur with increased total plow.

3) The same power level increase can bo obtained by reducing in some manner the overall reactor contral zone flow resistance, 1.0., larger nozies and plgtalis, chin-skinned fuel elemen+s, etc.

4) The unly tlae reducing the fringe flow resistance is of sure value in Increasing product1on is whon:

(a) Tho bulk tomporature $11 m i$ to to ilxod.

(b) The central zone flow resistance cannot be reasonebly decreased.

(c) And the reactor water plant can adequately provide the increased flow. 


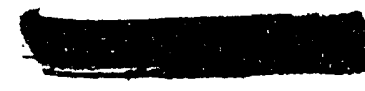

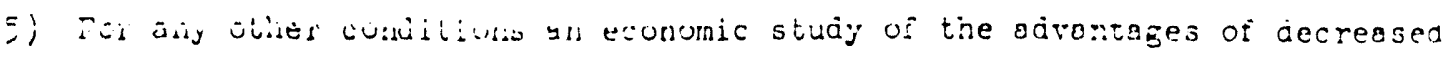

Eline or botal resistance as a function or central and friraze zone flows,

ripture 11mits, corrosion 110its, trip-after-instability 11mits, top-or-

annulus bo111ng $11 \mathrm{mlts}$, ant cross-heoder pressur1zation effects must be made.

It should be emphosized, horever, that on a short term basis, opening the Eringe orffices is a conienient. way of incressing production at constant bulk Ditlet temperature.

․ Pegr Riser Quenchinz

A second means of malntalning a constant effective bulk outlet temperature while increasing the reactor power level would be to add cold quench water to the rear risers. This method of increasing production was mentioned in a survey report (2) and is again sugzested by J. R. Young. (1) Let us f1rst consider the general case and in light of this examine Mr. Young's proposal. For the case of a complete cold water quench it would be added to the bottom of both rear risers. Under these conditions the cold water would mix with hot effluent all the way up the risers and it $1 \mathrm{~s}$ quite reasonoble to oxpect on effective mixing and quenching c: the effluent temperature. The problemo associated with this system are as inl1ows:

1) Th1s raw water flow would have to be at least as relabilo as the reactor Plow and have similar flow decay characterlatics. In other words a raw water quench that permitted a 5 percent increase in reactor power level for the same effective bulk outlet temperature would require a lower permissible bulk outlet temperature $1 f$ the nature of this raw water supply would mean an increase in the freguency of bulk effluent temperature surges.

2) Even with a well zncked up raw water oystem the very nature of the system with on incroase in the mulelpliclty of valves, pumpo, controls, otc., that could pall would Indicate the need for somo decrease in the allowble bulk erfluent temporature. 
j) The only time that the use of this system 16 surely 1 ndicated is as follows:

(a) The bulk temperature $11 \mathrm{~m} 1 \mathrm{t}$ is $\mathrm{elxed}$.

(b) No further increase in reactor flow can reasonably be obtalned because of water plant or reactor limitations.

(c) An economical means of providing effluent quench water is avallable.

(d) This quench water can be provided with assured adequate mixing with

the effluent before the top of the risers and assured flow rellabli1ty.

There 15 one possible advantage of this system in comparison with just an increase in reactor flow. If this system were not affected by a BPA electrical outage then 1t would tend to diminish the BPA outage effests by supply1ng a proportionaliy increasing amount of cold water quench as the reactor flow decayed. Th1s condition would tend to cancel the frequency effect ment1oned earlier and permit the bulk temperature limit to remain unchanged.

C'. Use or Eot Water Rec1rculat1ng System to Quench Water in Near Rear R1 ger

The speciflc use of this hot-water reclrculating sjstem es an effluent quench has several draw-becks. These are:

1) Insurficlent mixing distance.

2) No quench water added to one-hale the effluent in an effluent piplng lowpressure region, 1.e. the near riser.

These draw-backs are serious in thet adequate mixing of the whole effluent with quench water must be provided in a manner thet w111 limit effluent bo111ng at any point in the effluent system. Othersise the quench is ineffective in permitting higher allowable outlet water temperatures. For heat transfer calculations boundary conditions are assumed to stabalize at a distance siven by the equation(11) $L / D=.69$ (DW/ft) $)^{25}$. It can

(11) W. B. McAdame, "Heat Transmias1 on," PB. 225, IIIrd. Ed., McOraw-B111 (2954) 


\section{DECLASSIFIED}

$E W-5580111$ i.

Page 15

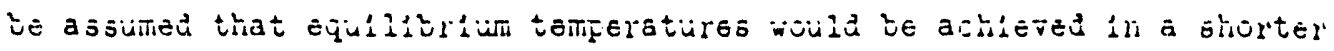

distance. However, this corresponds to a riser length of 130 it. or a cross-

over length of $160 \mathrm{ft}$. whereas the actual distance from the rear riser to the

top of the downcomer is only $11 \mathrm{ft}$. Consequently we dare not now assume any

slgniflcant degree of mixing of the far and near riser streams.

D. Venting of the Top-or-Downcomer

A system of an open vent ilne from the top of the downcomer to the reactor purge-gas stack has been suggested as a means of permitting an increased bulk outlet temperature. Mis has the advantage of reducing system pressures to prevent top-of-downcomer fallure. Th1s should then eliminate both excessive radiation problems from radioactive steam and any problem of excessive efpluent water leakage to the reactor bullding and surround1ngs. Bowever, this system has numerous disedvantages, including the followlag:

1) The outlet temperature monltor must be moved to the rear risers to avold the decrease in bulk temperatures beyond the downcomer as steem 18 flushed from 1 ts top. The present monltor would indlcate a corstant bulk outlet tempera. ture even though the resctor bulk temperature was rising.

2) With the top-or-downcomer vented to gleld atmospherlc prosiure $(<.5$ p815) the momontum effects induced by cross-over boling would be their grestest. There would be maximus stress on the entrance elbow and on the top cascado tray. 3) The vent ine would have considerable capecity requ1rements and would probably require shielding. For instance 1t 18 estimated that a 4 ft. diameter vent line would be required to handle the steam venting at $110^{\circ} \mathrm{C}$ with a maximum top-op-downcomer prensure of $0.5 \mathrm{ps}$. . Thls does not inelude an allowance for the olgniflcant volumes of alr and gases that would also be vented. .

4) Th1 large influx of otoam 1nto the rogular exhaust alr ack would tend to reduce the normal exhaust of reactor gases and wight even cause a temporary reversal of the contaminated air slow. 
Consequently it can bo concluded that the bulk effluent problem cannot be adequately handled merely by using the 6-1nch vent line from the top of downcomer to the flle exhaust stack.

F. Eppluont System Pressirization

One further manner of Increasing reactor production, w1th respect to bulk temperature 11mits 18 to pressurize the effluent p1ping oystem. This w111 protably involve installing complete now effluent piping from the top of the renr risers to the retention basin. It w11l involve a study of the effects of - marked increase in vapor emlssion from the retent1 on basin, and one further problem w11l bn the pressurization produced by two phase flow at the dischurge to th1s effluent system. W1th th1s offluent system pressurized there w111 bo - time $19 \mathrm{~g}$ of atout a minute between an increase in bulk epeluent temperaturo caused by power surgo or a vater 10se and the effluent pressurization offect. By th1s time, in every transint cond1tion except a slow or power change too ome 11 to cause a Beckman or a Panell1t trif, the reactor w11l bo scrammed seconds before thore 18 in increase in system pressurization. Therefore, except for the following difflcult1es th1 system poses no ser1ous operating problems.

1) A marked increase in vapor 1088 from the basin as the bulk outlet temperatures are increased.

2) A signiflcant installation cost.

F. Program for Increased Production Through Bulk Effluent Temperature Increeses or Blik Tomperatura Lim1t C1rcumvention

1. Gerieral

At the prosent t1me wo do not have answers to the many problems posed In the narlier sertione of this report. Therefore, besore apecisle ochedulo can be decided upon for increesed production by any of the proposed mothode it is necessary to secure anovers to many of these problems. 


\section{DECLASSIFIED}

$\operatorname{Min}-5,2,8 \cap 1<D$

Page 17

In other words it is lmportant to make an overall culdy of this problem before we can dec1de with any englnoering accuracy the best means of securing this production increase. This w111 require a program or laboratory experiments. In-plle testing, and engineering study. In the rollowing sections this program is presented in sufficlent dotall to atart mir fregram studies.

2. Laboratory Studies

a. Washington State Fydraulics Leboratory

(1) Water Temperature Mixing:

One of the 1mportant problems with respect to the bulk efrluent problem is determining the rapldity of temperature mixing in the weter after the confluence of two water strens at different temperatures. Ittle experimental insormetion on this subject appears avallable; yet 1t has a ansfcant bearlng upon the degreo of plashing that wo could obtain at the top of the rear risers and at the entrence to the downcomer. Therefore a theoretical and scelod-down model study should be made of these temperature mixling effects. Basicaliy we need to know the effect of velocity, temperature, cross-eectional area, and geometry upon the degree of water temperature mixing at various distances downstresm from the confluence of the mixing streams.

A suggested means of completing this investigation would be to construct soveral models simulating the effluent systom using clear plastlc components. These should range in slze from $6^{*}$ to $12^{n}$ diameter or Inrger. A careful analysio of the flow problem Involved would be required to decide upon the rolative importance of the varlous sluld dimensionless numbers, (Reynold's No., Frondo No., etc.). With theso differant alzes and with flow velocitios adjusted to approach model 
simultude then 1t may be possible to extrapolote to reactor conditions. At least our knowledge of the mixing conditions should be much Improved.

Probably the b1g8est difflculty in such a testing program will be satisfactory measurement of the lluid local temperatures. The information fram th1s study w11l be useful in three months time and certainiy should be required by April of 159.

(2) Scale Model Boll1ng:

With these scale models for water temperature mixing it would be very desirable to model effluent pressurization effecta. The purpose of these tests would be to measure the degree of pressure surges produced by varlous degrees of trensient boling and the momentum erfects produced upon critical components of the p1p1ns model. W1th varlous nominel operet1ng water temperatures and slows - sudden Increase in weter temperature would be $1 \mathrm{mposed}$. H1gh speed sensing elements would then be used to measure pressure and momentum effects.

The purpose of these tests would be to epply the pressure and momentum offects to an onalysis of the maximum allowable operating conditions for present effluent plping system and also to any design of aressurized system. These tests should be performed with and w1 thout top-or-downcomer vent1ng.

b. Thermal Hydraul1c Oneration

In addition to the hydraulic laboratory otudies proposed for, it may be necessary or denirable to mun the larger tlow or higher temperature parte of th1s of luent mock-up otudy in the 189-D Thormal Eydraul1cs Laboratory. In this case 1t 10 antlcipated that a program agroeablo to oursolves, Thermel Bydraulics and . Washington State consultant can be arrenged. 


\section{DECLASSIFIED}

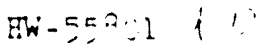

Page 19

\section{c. Mechanical Develorment Operat1on}

There $1 \mathrm{~s}$ now a cross-hender mock-up under the direction of $C$. W. Botsford in the 108-D Bulld1ng. Th1s mock-up should be used to test the sollowins cond1t1ons;

1) Eefect of Introduclng one or several oriflcos in the header upon tube outlot pressures, and possible cavitation erosion downtram ne these orifice plates.

2) Cavitation erosion in the cross-header at points where cavitation may occur, 1.e. oppcisite the flgtall entrances and just downstream of the elbows.

3) The effect of supplying port of the crose-header flow from slmulated tubes 5 to $20^{\circ} \mathrm{C}$ above the cross-header saturation temperature with the bulk cross-beader rluid near saturation.

4) The determination of the pibretion and stress effects produced in the cross-header at these higher temperatures.

With these problems to be solved the following testing procedure 1s suggested:

1) With the crose-header loop c1rculating at $90^{\circ} \mathrm{C}$ and w1th no cross-header orlf1ce plates rase the $100 \mathrm{p}$ temperature to $100^{\circ} \mathrm{C}$ wth not more than 8 p816 fressures at the cross-heeder outlet, and c1rculate for a time sufficlent to Give Indications of carltation. A careful comparison of all oystem pressures should be wade at the $90^{\circ}$ point and the $1 \mathrm{n} 1 \mathrm{t} 1 \mathrm{al}$ and final $100^{\circ} \mathrm{C}$ point.

2) Sieliar tests should be run at cross-header temperatures up to $120^{\circ} \mathrm{C}$ and cross-header outlet pressures as low as 8 psig.

3) W1th the increased temperature paremeter 1nvestigated in en open crossheoder the same tests should be repeated with varlous cross-header oriflces in order to determine the desirable ras croes-hoeder orifleing for hifhor temperneure renctor opernelon.

The rooults from these teets wlll be noedod for the $B$ or C-Renctor Bulk Outlet Tesperaturo Production Test. Mhls test 18 tentat1vels scheduled ror 


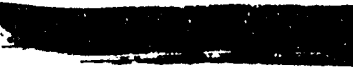

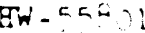

Page 20

July or Aligust of 158 .

in order to achlere the dosired cross-header temperatures at low enough

Fressures 1t w111 be necessary to quench the pump inlet to prerent pump

cavitation. Mis will require reheating the loop between the pump and the

test sectlon. Therefore, plans should be started for loop modffications

such as:

(1) Insertion of guench water far enough avay from the pump to ensure - dequate mixing.

(2) Insertion of steam heating heat-exchanger between the pump and the cross-header.

(3) Installation of sultable controls including temersture measurements to permit automatic operation of the loop with only routine lnspection about twice shift.

\section{d. Instrument Development Operat1on}

There are a number of lnstrument dovelopment facets of th1s groposed 1acrease in bulk outiet temperstures. One 1mportant problem is in the proper location of revised bulk offluent temperature elements. For the proposed production test and for several of the other proposals for increasing the bulk-11mited production the present bulk outlet tempereture elements w11l not give a true indication of outlet temperatures whenever any g1gafficant steem evolution occurs from the top of the downcomer. Therefore, new temperature elements should be lnstalled at soveral positions in the rear risers between the top cross-header and the cross-over. The dosirable location is one high enough bove the top-cross-hoader to ensure a rensonably mixed water temperature and a posticion far enough bolow the

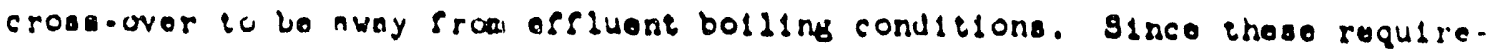
ments are probably 1ncompatible It vill be necossory to place tempereture - loments at ceveral polnts on the rloers.

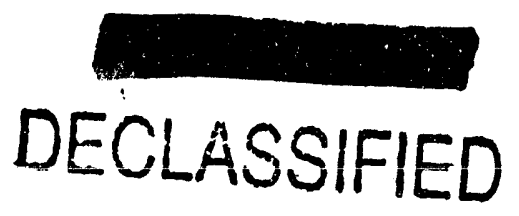


Two other development problems aro high speod pressure measurements In the effluent system and strain-gege stress measurements at critical structural polnts. With this production test tentatively programmed for the surmer of 158 it w11 be necessery to organize the necessary equipuert and know-how on both of these problems to carry out the froduction test

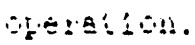

- Nechanical Development Oneration "B"

One of the most important problems asoscleted with this increased tempereture operation 18 the poss1b111ty of cav1tation erosion limlting the service 11 fo of the effluent system and causing serious $108 \mathrm{ses}$ in production. As another approch to th1s problem that does not require fuld scalo operation. or any reactor down-t1me 1418 recomended that cav1tation studies be made using the method proposed by Rob1nson, Bolmes and Le1th. (12) Th1s equ1pment 18 generally used to compere the cavitation resistance of different materials. Bowever it may be possible to adapt tb1s equipment to study1ns the offect of operating chenges upon the same material. An indication of the effect of outlet temperature 1ncreases mag bo determined by making these cav1tat1on tests at verlous conditions of temperature, pressure and $\mathrm{pH}$ (13)

\section{(3) Des1gr Studies}

\section{- Reactor Mod1rication Design Oneration}

In connection with the suggested alternatives to 1ncreased bulk outlet temperatures it will be necessery to clearly deflae the design and construction coste assoclated with each proposal. Therofore, 1 it 18 rocommonded that those proposed mothod be etudied and a sultable doelgn sor each cade be obtalnod. The two methoda tiat involve the alnimum amoune of efsluent plping changes are:

i2) Rotlnson, BOImes, Lalgh, "Progrea Roport on 8tandardizat1on ar the v1bratory Cavitation Tost," ASME-56-A-85. (1956)

23) i.M. Fnx, ir., Porsonal Communication. $4-3-58$. 


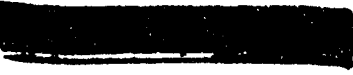

Twi-kr..: :

Page 20

July or Aligust of 158 .

in order to echlere the desired cross-header terperatures at low enough

fressures it w11l be necessary to quench the puep inlet to prerent pump

cavitation. Th1s w11l require reheating the loop between the pump and the

test section. Therefore, plans should be started for loop modifications

sisch as:

(1) Insertion of quench vater far enough avey from the pump to ensure adequate mixing.

(2) Insertion of steam heating heat-exchanger $t$ stween the pump and the cross-header.

(3) Installation of sultable controls 1rinluding temersture measurements

to permit autometic operation of the loop with only rouilne inspection about twice a shft.

d. Instrument Development Operation

There are a number of lastrument development facets of th:s profosed increase in bulk outlet temperatures. One 1mportant problem 1. In the proper location of revised bulk erfluent temperature elements. For the proposed production test and for several of the other proposals for increasing the bulk-11mited production the present bulk outlet temperature elements w1ll not give a true indication of outlet temperatures whenever any signiflcant steem evolution occurs from the top of the downcomer. Therefore, new temperature elements should be lastalled at several positions in the rear rlsers between the top cross-header and the cross-over. The desirable lucation is one hifh onough above the top-cross-hoader to ensure a reasonobly mixed water temperature and a pcsition far enough below the cross-over to be avay frow ofsluent bollins conditions. Since those requirements are probebly 1ncompetible lt vill be necessary to place temperature - lomente al coveral polnte on the rleers. 


\section{DECLASSIFIED}

c. Mechanical Develorment Operation

There is now cross-hender mock-up under the direction o: $C$. W. Botstord in the 108-D Bu1ld1ng. Th1s mock-up should be used to test the follow:ng cond1t1ons;

1) Eefect of 1ntroducing one or several orlelces in the header upon tuhe outlet pressures. and possible cavitation erosion domstranm ne thase orifice plates.

2) Cayitaiton erosion in the cross-header at polnts where cavitation may occur, 1.e. opposite the fletoll entrances and just downstream of the elbors.

3) The effect of supplying pert of the crcss-header rlow from simulated tubes 5 to $20^{\circ} \mathrm{C}$ above the cross-header saturation temperature with the bulk cross-beader Plu1d near saturation.

4) The determination of the vibration and stress effects produced in the cross-beeder at theso hlgher temperatures.

With these problems to be solved the followlng testing procedure 18 suggested:

1) With the cross-header loop c1rculating at $90^{\circ} \mathrm{C}$ and with no cross-header orlf1co plates ralse the 100 temperature to $100^{\circ} \mathrm{C}$ wth not more than 8 psig fressures at the cross-header outlet, and circulate for a time sufficlent to Glve ladications of cavitation. A careful comparison of all system pressures should be wade at the $90^{\circ}$ polnt and the $1 \mathrm{nit10l}$ ad sinal $100^{\circ} \mathrm{C}$ polnt. 2) Slallar tests should be run at cross-header temperatures up to $120^{\circ} \mathrm{C}$ and cross-header outlet pressures os low os 8 psig.

3) W1:t. the increased temporature porometer invest1gated in an open crossheoder the same tests should be repeated with varlous crose-heder orlelces in order to determine the dealrable rear crose-heeder orfelcing for higher tamernture reactor operation.

The results frow these tests w11l be needed for the B or C-Reactor Bi:l. Outlet Terpernturo Production Test. Mh1s tost 18 tentatively ocheduled Par 

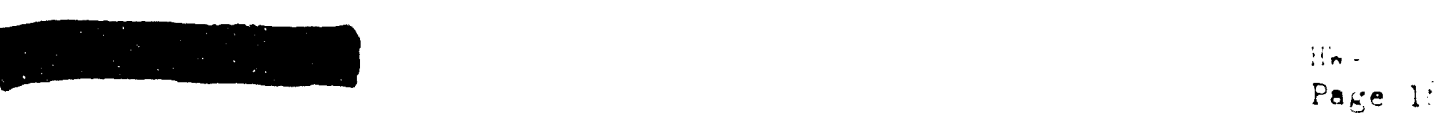

slaultude then 1 t may be posolble to extrapolato to reactor

cond1t1ors. At least our knowledge of the mixing conditions should

be much 1 mproved.

Probably the blegeat difflculty in such o teating program will

be satiofactory measurement of the fluld local temperatures. The 1n-

formation fram this study w11l be voeful in three montho time and

certainly should be required by April of 159.

(2) Scale Model Boll1ng:

W1th these scale models for water temperature mixing $1 t$ would be very desirable to model effluent pressurization effects. Tho purpose of these tosts would be to measure the degree of pressure surges produced by varlous degrees of transient boll1ng and the momentum effecta produced upon critical components of the p1p1ng model. With varlous nomlnal operat1ng water temperatures and lows a sudien Increase in weter tomperature would bo 1mposed. F1gh opeed sensing elements would then be used to measure presaure and womentur efrects.

The purpose of these tests would be to apply the pressure and momentum effects to an analysis of the maximum ellowable operet1ng condltions for preaent effluent plping system and also to any design of a pressurized syotem. These tests should be performed with and without top-of-downcomer vent1ng.

b. Thermal Bydraul1c Oneration

In addition to the hydraul1c laboratory otudies proposed for, it may be necnesary or denlrable to mun the lerger elow or higher tomporature parte of this offluent mock-up otudy in the 189-D Thormal Bydraul1cs Laboratory. In this case 1t 1s antlcipated that a prograd agreoable to ourselves, Thermal Bydroul1cs and Washington Stoto consultant can bo arranged. 


\section{DECLASSIFIED}

$\min -7,-, 301<1\}$

Fage 1T

In other words it 18 lmportant to makn an overall atudy of this problem before we can declde with any englneerling accuracy the best means of securling inls froduction increase. This w111 require a program or inboratory experiments. In-plle teoting, ond engineerling study. In the rollowing sections this program 1s presented in supplcient detall to otart nit fogeram studies.

2. Loboratory studies

a. Washington State Rydraul1cs Laboratory

\section{(1) Wator Temperature M1X1re:}

One of the 1mportent probleme with respect to the bulk efrluent problem 18 determining the rapldity of temperature mixing in the water after the confluence of two vater otreame at different temperatures. Littlo experimental information on this oubject appears avaliable; yet it hes a signicant bearing upon the degree of plashing that wo could obtain at the top of the rear risers and at the entrance to the downcomer. Therefore a theoret1cal and acaled-down model tudy should be made of these temperature mixing effecte. Basically we need to know the effect of veloc1ty, temperature, cross-8ectional area, and geometry upon the degree of water temperature mixing at varlous distances downstrean from the confluence of the mixing streams.

A suggester means of completing this investigation would bo to construct several models olmulating the effluent system using clear plastle components. These should range in size from $6^{n}$ to $12^{n}$ diameter or lnrger. A cereful analysis of the flow problem involved would be requlred to declde upon the relative importance of the varlous eluld dimensionless numbers, (Reynold's No., Fronde No., etc.). Wlth these different 1200 and with flow velocitles adjusted to epprach model 


\section{DECLASSIFIED}

HW $-55801 N^{\prime} D$

Page 22

(a) Adding quench weter to the bottom of the rear cross-headers.

(b) Venting the top of the downcomer.

Bowever, before declding upon elther of these methods we should

know the costs envisloned for full effluent system pressurization. The resson for this 18 that even though thase costs wlll apparently be much

higher than the quench or venting methad the possible production gain -hould also be much increased.

4. Englnoering Studies

- Reactor Ing1neerling Opernt1 on

It w1ll be necessery at 811 t1mes for $R$ \& $E$ to have the safoty aspects of this problem vell in hand. It will be our obligation to analyze proposed operation and potential problems and to 1ndicate the safe 11 mits for any proposed des1ga and procedure. At the same time it will bo 1mportant to 200k for poselble relaxat1ons or operating 1mprovemente thet w1ll permit safe reactor oneration at oven higher power levele.

b. Procees Analyale Operation

Certainly in the case of Iringe zone cooling, and probably in the cholce of en alternate to Increased bulk outlet temperatures, 1 w1ll be necessary to make a complete analyels of the relative merits of the different methods of Increasing production. In fringe zone coollng wo must consider the merite of sacrffeing some central zone flow in order to obtain net increase in reactor slow and thus power level at a constant bulk outlet temperature. Bere care must be taken to consider the pump characteriotics and the varlous Individuel tube 11 mite that may be more restrictive than the bulk outlet tomporature dimlt.

In the case of the alternate plping methods 1 it 10 important to consider not only the deelgn coste but the potentiel hazerd costs assoclated with each. These are discuesed brierly in pages 23 to 13 of thie roport. 


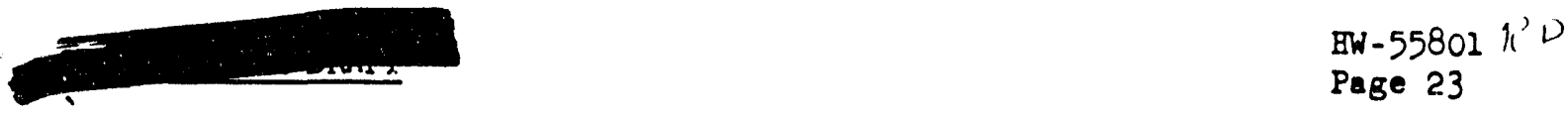

In the case of the effluent system pressurization, the increased cosis chould be considered in conjunction with the possibility of a considerable 1ncrease in production. Bere again the increased production will depend upon ralsing other limits beside the reactor bulk outlet temperature. Therefore, the value of effluent pressurization w1ll depend upon the success of development efforts to ralse these other limits associated w1th reactor operation.

\section{CONCLUSIONS}

At the present time our bulk temperature l1mit is based upon an analyo1s of the costs to be assoclated with possible problems at elevated bulk temperatures comblned with the high value of 1ncreased production. Bowever, both the damage effects of temperature surges and the1r frequency are only estimates. Consequently, our cost data 18 inherentls inaccurate although considered to be conservativels high. In ralsing th1 bulk temperature limlt, therefore, there are throe 1mportant considerat10ns. First, it 18 essential that more fundemental reector deta be obtelned before wo nre gustified in releing reactor bulk $11 \mathrm{mlt}$ te further. 8econdly, because these I1mite are besed upon possible effluent demage conditions, it 1e essential that a carerul production test proceduro be adopted. And thirdly, because wo aro considering the operation of the reactors up in the renge of progressive effluent sjster damage 1t 18 not recomended that such operation be considerel on a permanent or long term bas1s. In other words, it is not considered good operating pract1ce, desplte the oconomic incentive, to operate the reactore continuously at a point where cry severo transients w1l cause plping damage. It can be concluded that such operation eren without severe transients is inherently damaging to the plping system and prolonged operation under these conditions could lead to more severe offluent damage than the short term tests would indicate.

Along with the production test for increasirs the bulk outlet temperatures several methods have been proposed for gaining the equivalent production 1ncrease by other meens. Before the best means of obtalning a long-term solution to this problem can

$$
\text { DECLASSIFIED }
$$




\section{DECLASSIFIED}

be reached, studies of all the varlous proposals must be completed, at least in sufficlent detall to estimate production gains, installation costs, and reactor safoty considerations. Therefore we should perform an andysis of:

1. Fringe zone quenching.

2. Rear riser quenching.

3. Top of Downcomer venting.

4. Effluent system pressurization.

These should be completad by the epproprlate IPD organlzation to the extent necessary to reach $11 \mathrm{rm}$ sconomic and safety conclusions concerning the best of the four methods.

In this resfect the suggested laboratory stud138 of:

1. Cross-beader high temperature flow studies.

2. Effluent system scale studies.

3. Water temperature mixing studies

are all 1mportant adjuncts to the actual production test 1tself in establishing maximum bulk operating l1w1ts.

In a report of this neture involving the programing of possible work for many different Banford groups it is obvious that allowance mast be made for mang different points of view and for the fltting in of this suggestud vork with many other problems. Thereforo it 1s hoped that this report will serve to point out the basic problems, and their possible solutions; and to stimalate the development of an active organized effort towards the achievement of the desired production goals.

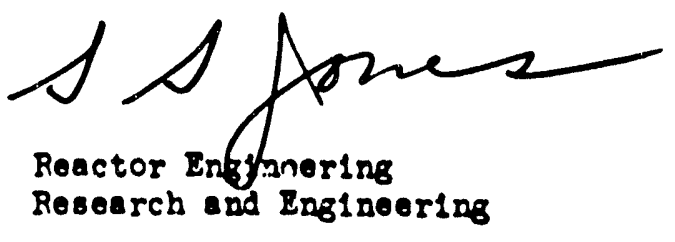

SS Jones:bs 

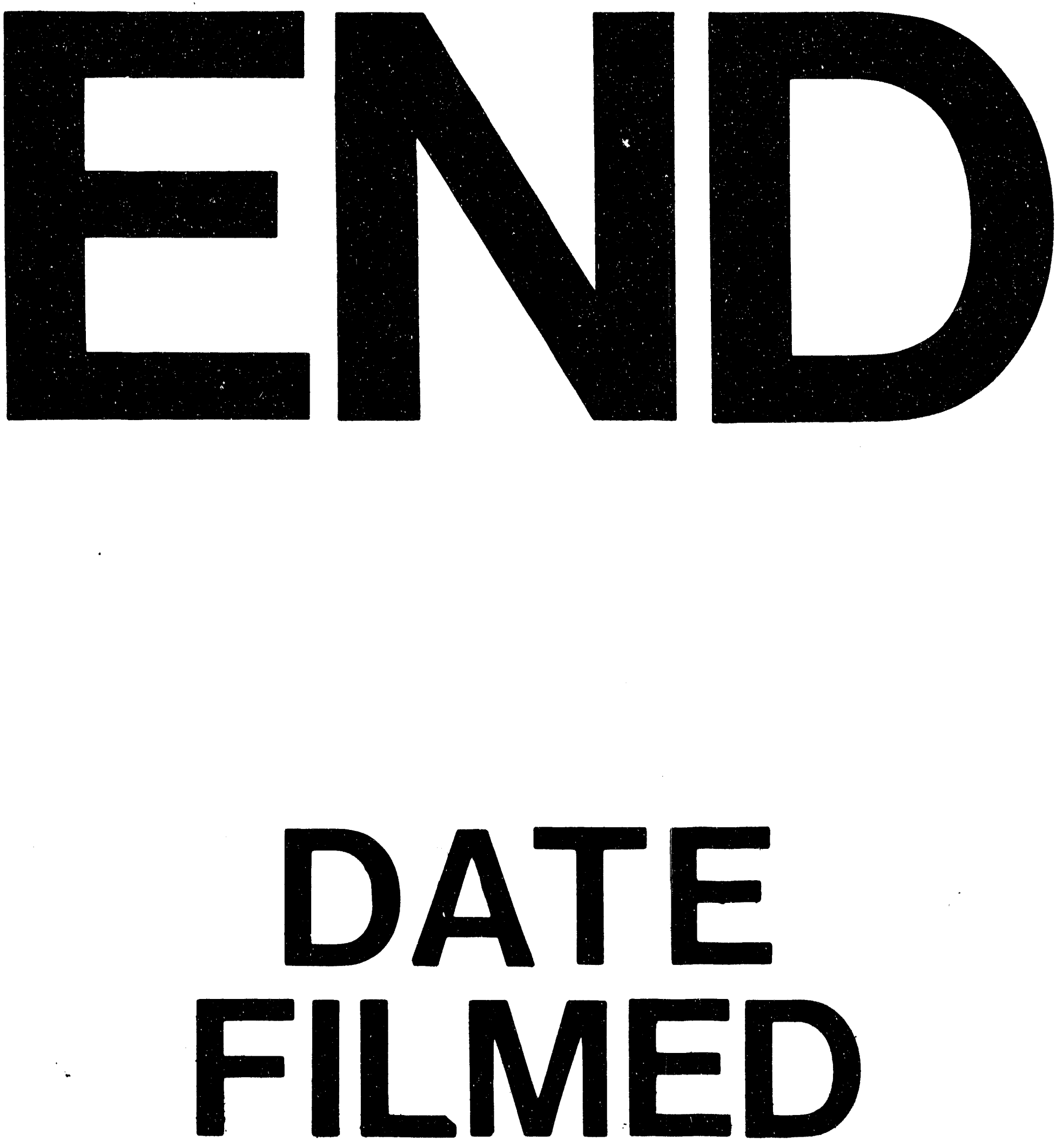

1

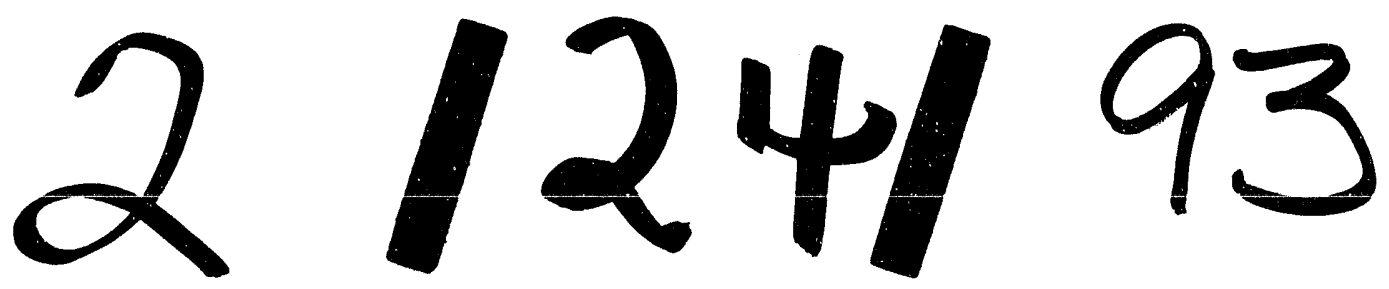


